\title{
Introduction
}

\section{AIM AND SCOPE}

This book aims to describe regulatory reforms in Japanese public utility industries. Since the early 1990s, when I began research on privatization and regulatory issues as related to Japan, it has become clear how little information about Japanese regulatory reform has been written in English. Because of the lack of information available in English, it has been difficult both to discuss Japanese public utility industries in international forums, and to explain Japanese regulatory reform to foreign students in Japan. This book results from my desire to facilitate understanding in the international community about regulation and reform in Japanese public utility industries, and to create an effective tool for the instruction of such matters to my students at Kobe University.

It is my firm belief that information about regulatory reform in Japanese public utility industries should be made more widely known outside Japan. Unlike researchers in the natural sciences, researchers in the social sciences cannot be expected to conduct experiments, and this fact makes it vitally important to observe what consequences result from regulatory reforms, wherever they are undertaken. It is useful to look at regulatory reform in Japan, as the Japanese approach differs markedly from that in other areas, particularly European countries and the U.S. The Japanese approach, characterized by its slow steadiness, has been quite moderate compared to that of Europe, especially the UK.

There are many variations in the degree of success among public utility industries, and there have also been failures in regulatory reform. A successful example of privatization is the former Japan National Railway. Regulatory progress remains slow, however, in the water supply industry, with many smaller water supply organizations suffering from faulty management. Furthermore, even though regulatory reforms have been introduced in the bus industry in Japan, little or no improvement has been seen, even in large cities. Thus, there are many cases for which Japan needs to look to other countries for lessons in making regulatory policy.

My first goal is to explain the main regulatory structure and 
regulatory reforms in eight Japanese public utility industries: electric power, gas utility, water supply, railway, local bus, postal service, telecommunications, and broadcasting, all for the time period between 1990 and 2010. Regulatory reforms as referred to in this book include organizational changes such as privatization and restructuring. For cross-industry cases, selected topics on Japanese public utility regulatory issues are included, such as yardstick regulation, privatization, and structural reforms. An explanation of regulatory reform in each industry is included as well. Not included are such social regulation issues as safety and environment, which are important but which will be reserved for treatment in a future work.

\section{STRUCTURE OF THE BOOK}

The book consists of five parts and fourteen chapters. Part I, Theoretical Background of the Public Utilities Industry, establishes the theoretical framework for subsequent explanations of regulatory reforms and practices in public utility industries in Japan. Chapter 1, 'Regulation,' explains general economic regulation and the rationale for public involvement. This chapter deals with the definition of regulation, options for public involvement, kinds of regulation, major regulations, the rationale for regulation in public utility industries - traditional or basic - regulations in public utility industries in Japan, the recent trend toward incentive regulation, regulatory policy in general, and regulatory failures. Chapter 2, 'Public and Private Provision,' focuses on the form of provision in public utility industries. This chapter contains a rationale for public provision, a definition and classification of public corporations, an overview of private provision and efficiency, empirical evidence affecting efficiency, and the definition, kinds, and purpose of privatization from a Japanese perspective, with attention to the international outlook as well. Structural reforms are also explained in this chapter.

Part II of the book, Energy and Water Supply Industries, describes the practices of regulation and regulatory reforms in the electric power, gas utility, and water supply industries. Chapter 3, 'Electric Power,' describes the market structure, the rate system and major price regulations, and the process of liberalization, which occurred four times (1995, 2000, 2004, and 2005), in the electric power industry. Chapter 4, 'Gas Utility,' is explained similarly. In this chapter, the market structure, the rate system and major price regulations and major regulatory reforms, occurring in 1995, 1999, 2004, and 2007, are described. Chapter 5, 'Water Supply,' follows a similar pattern. Although the water supply 
industry has not been subject to regulatory reforms, there is an explanation in this chapter of the characteristics of the industry's structure and regulations, followed by a discussion of how regulatory reform relates to this industry.

Part III, Transport Industries, describes regulation and regulatory reform in the rail and local bus industries. Of all public utility industries in Japan, the railway industry has been most extensively reformed. In Chapter 6, 'Railway,' the organizational structure of the rail industry, regulations regarding entry and exit, fare, rail track fees, and regulatory reforms are explained. In this chapter, I discuss the competitive situation in the railway industry, noting that competition policies taken in Japan differ from those favored in Europe. Chapter 7, 'Local Bus,' describes the practice of regulation and regulatory reforms in local bus industries. This chapter includes an explanation of the organizational structure of the local bus industry in Japan, entry and exit regulations, fare regulations, regulators, subsidy schemes, and the main regulatory revisions. Included also is a discussion of the effects of regulatory reform on the local bus service industry in Japan.

Part IV, Communications Industries, describes practices related to regulation and regulatory reforms in the postal services, telecommunications and broadcasting industries. Chapter 8, 'Postal Services,' explains characteristics of the postal service industry, its industrial structure, the current mail situation, and kinds of post offices, postal service regulations such as entry regulation, price regulation and universal service obligation, and liberalization in postal services. Chapter 9, 'Telecommunications,' describes regulatory reforms mainly focusing on the telephone industry. This chapter contains information about the market structure of the telecommunications industry, market size, the number of telephone customers, the major telecommunications companies, regulations such as entry, price, and inter-connection regulations, and liberalization in the telecommunications industry in 1985, 1999, 2001, and 2003. Chapter 10, 'Broadcasting,' describes major regulation issues, focusing on the industrial structure of the broadcasting industry, market size, the kinds and numbers of broadcasting companies, broadcasting industry regulations, and regulatory reforms in the broadcasting industry.

Part V, Selected Topics in Regulatory Reform in Japan, describes several important points as they relate to several Japanese industries. Chapter 11, 'Yardstick Regulation,' discusses the theory and practice of yardstick regulation as applied to public utility industries in Japan. This chapter includes an overview of yardstick regulation, a summary of how it is applied in practice to four Japanese public utility industries - electric 
power, gas utility, rail, and bus service-and an assessment of the effectiveness of yardstick regulation based on previous empirical research. Chapter 12, 'Universal Service Obligation,' treats a matter under serious political debate in Japan. This chapter lists the characteristics of the universal service system in Japanese public utility industries. The main items in this chapter are a definition of universal service in Japan, an explanation of universal service as related to postal services and the telecommunications industry, the structure of the universal service obligation system, the calculation method of universal service costs, and empirical results related to universal services in Japan. Chapter 13, 'Privatization and Structural Reforms,' uses the Japan National Railways, the highway public corporations and the Japan Post Public Corporation as examples of reform. These organizations were chosen because their experiences with reform embody characteristics of the Japanese approach (Highway and Japan Post), they are classic examples of the basic Japanese philosophy to restructuring (Japan National Railway), and there has been ample time to glean information and results for performance evaluation (Japan National Railway). Last, Chapter 14, 'Private Sector Involvement,' refers to including private sector participation in the provision of public services in Japan. This chapter explains and discusses the so-called 'private sector style management' in Japan, Japanese style PFI, the designated manager system, and the local independent administrative institution scheme.

\section{ACKNOWLEDGEMENTS}

This book is based on the research of others, government information, my own lecture notes, my own research, and my research work with co-authors. Without the work, help, and support of all these people, this book would never have been completed.

Although it is not possible to list all their names, I would like to thank many members of the Japanese Society of Public Utility Economics, the Japanese Association of Transport Economics, the Japanese Economic Association and Kobe University.

I would like to thank the co-authors of my previous research work: Hideo Kozumi (Kobe University), Noriaki Matsushima (Osaka University), Keizo Mizuno (Kwansei Gakuin University), Kiyoshi Nakamura (Waseda University), Noriyoshi Nakayama (Nagoya City University), Hiroshi Sasaki (Kobe University), Kenichi Shoji (Kobe University), Tomoyasu Tanaka (Kinki University), Takuya Urakami (Kinki University), and Shuji Uranishi (Fukuyama Heisei University). 